\title{
ANTI-SECESSION LAW OF THE PEOPLE'S REPUBLIC OF CHINA
}

\author{
Anti-Secession Law of the People's Republic of China \\ Adopted at the Third Session of the Tenth National People's Congress on 14 \\ March 2005
}

\section{Article 1}

This Law is formulated, in accordance with the Constitution, for the purpose of opposing and checking Taiwan's secession from China by secessionists in the name of "Taiwan independence", promoting peaceful national re-unification, maintaining peace and stability in the Taiwan Straits, preserving China's sovereignty and territorial integrity, and safeguarding the fundamental interests of the Chinese nation.

\section{Article 2}

There is only one China in the world. Both the mainland and Taiwan belong to one China. China's sovereignty and territorial integrity brook no division. Safeguarding China's sovereignty and territorial integrity is the common obligation of all Chinese people, the Taiwan compatriots included. Taiwan is part of China. The state shall never allow the "Taiwan independence" secessionist forces to make Taiwan secede from China under any name or by any means.

\section{Article 3}

The Taiwan question is one that is left over from China's civil war of the late 1940s. Solving the Taiwan question and achieving national re-unification is China's internal affair, which bows to no interference by any outside forces.

\section{Article 4}

Accomplishing the great task of re-unifying the motherland is the sacred duty of all Chinese people, the Taiwan compatriots included.

\section{Article 5}

Upholding the principle of one China is the basis of peaceful reunification of the country.

Asian Yearbook of International Law, Volume 11 (B.S. Chimni et al., eds.)

(C) 2006 Koninklijke Brill NV. Printed in The Netherlands, pp. 347-349. 
To reunify the country through peaceful means best serves the fundamental interests of the compatriots on both sides of the Taiwan Straits. The state shall do its utmost with maximum sincerity to achieve a peaceful reunification.

After the country is reunified peacefully, Taiwan may practise systems different from those on the mainland and enjoy a high degree of autonomy.

\section{Article 6}

The state shall take the following measures to maintain peace and stability in the Taiwan Straits and promote cross-Straits relations:

(1) to encourage and facilitate personnel exchanges across the Straits for greater mutual understanding and mutual trust;

(2) to encourage and facilitate economic exchanges and cooperation, realize direct links of trade, mail and air and shipping services, and bring about closer economic ties between the two sides of the Straits to their mutual benefit;

(3) to encourage and facilitate cross-Straits exchanges in education, science, technology, culture, health and sports, and work together to carry forward the proud Chinese cultural traditions;

(4) to encourage and facilitate cross-Straits cooperation in combating crimes; and

(5) to encourage and facilitate other activities that are conducive to peace and stability in the Taiwan Straits and stronger cross-Straits relations.

The state protects the rights and interests of the Taiwan compatriots in accordance with law.

\section{Article 7}

The state stands for the achievement of peaceful re-unification through consultations and negotiations on an equal footing between the two sides of the Taiwan Straits. These consultations and negotiations may be conducted in steps and phases, and with flexible and varied modalities.

The two sides of the Taiwan Straits may consult and negotiate on the following matters:

(1) officially ending the state of hostility between the two sides;

(2) mapping out the development of cross-Straits relations;

(3) steps and arrangements for peaceful national re-unification;

(4) the political status of the Taiwan authorities;

(5) the Taiwan region's room of international operation that is compatible with its status; and

(6) other matters concerning the achievement of peaceful national re-unification.

\section{Article 8}

In the event that the "Taiwan independence" secessionist forces should act under any name or by any means to cause the fact of Taiwan's secession from China, or that major incidents entailing Taiwan's secession from China should occur, or that 
possibilities for a peaceful re-unification should be completely exhausted, the state shall employ non-peaceful means and other necessary measures to protect China's sovereignty and territorial integrity.

The State Council and the Central Military Commission shall decide on and execute the non-peaceful means and other necessary measures as provided for in the preceding paragraph and shall promptly report to the Standing Committee of the National People's Congress.

\section{Article 9}

In the event of employing and executing non-peaceful means and other necessary measures as provided for in this Law, the state shall exert its utmost to protect the lives, property and other legitimate rights and interests of Taiwan civilians and foreign nationals in Taiwan, and to minimize losses. At the same time, the state shall protect the rights and interests of the Taiwan compatriots in other parts of China in accordance with law.

\section{Article 10}

This Law shall come into force on the day of its promulgation. 